\title{
Uncommon presentation of a common disease
}

\author{
Sathya Narayanan Renganathan, Sunitha Vellathussery Chakkalakkoombil
}

Department of Radiology, Mahatma Gandhi Medical College and Research Institute, Pondicherry, India

\section{Correspondence to} Dr Sathya Narayanan Renganathan, sathyadr88@ymail.com

Accepted 14 June 2014
CrossMark

To cite: Renganathan $\mathrm{SN}$, Chakkalakkoombil SV. BMJ Case Rep Published online: [please include Day Month Year] doi:10.1136/bcr-2014204901

\section{DESCRIPTION}

A 41-year-old man with no comorbidities presented with obstructive jaundice of 2 months duration. Abdominal ultrasound undertaken at another institution revealed choledocholithiasis and he underwent open laparotomy. Intraoperatively a solid pancreatic head mass was found which raised the suspicion of malignancy. A biopsy was taken from it and surgery was deferred. Postoperative contrast-enhanced CT and MR cholangio pancreatography revealed a heterogeneous mass lesion in the head of the pancreas (figure 1), short segment strictures (figure 2) of common bile duct (CBD) and choledocholithiasis. A chest radiograph revealed an inhomogeneous opacity in the apex of the left lung and the tissue taken at operation showed features suggestive of tuberculosis including acid-fast bacilli on Ziehl-Neelsen staining.
Isolated pancreatic-tuberculosis is an extremely uncommon disease. The reported incidence is $2.1-4.7 \%$ in miliary tuberculosis ${ }^{1}$ and it typically presents as a pancreatic head mass. Cases are either identified unexpectedly at operation or suspicion is raised on cross-sectional imaging undertaken as part of investigations for abdominal pain. Ultrasound and CT cannot easily differentiate between malignant and tuberculosis-related masses and a recent trend is to use endoscopic-ultrasound and fine-needle aspiration cytology analysis for diagnosis $^{2}$ which improves the diagnostic yield. Tuberculous strictures of CBD also seen in this case has been reported previously. ${ }^{3}$ Regions where tuberculosis is common, any mass in the head of the pancreas should raise the possibility of tuberculosis and tissue diagnosis should be obtained before proceeding to invasive procedures as pancreatic

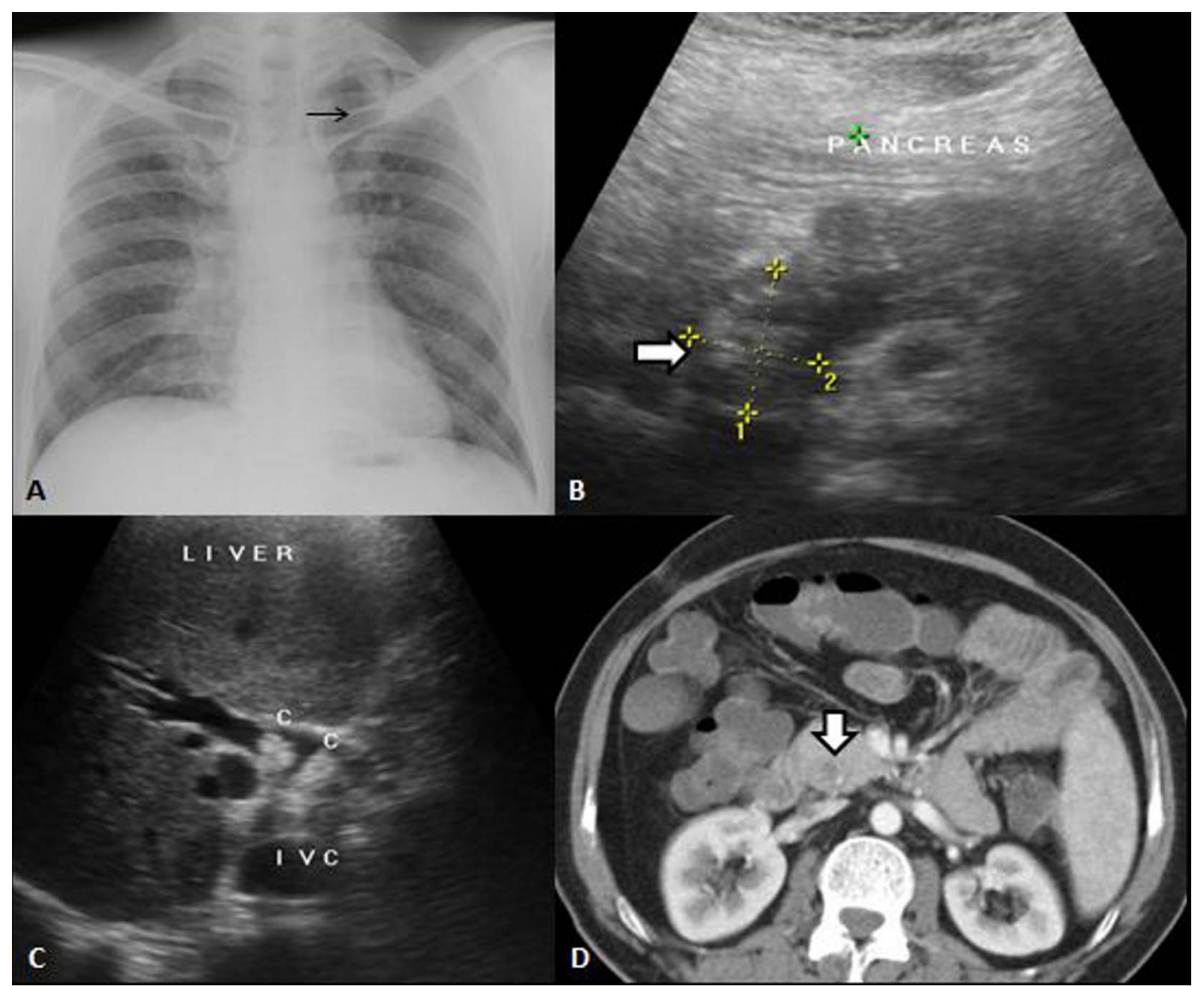

Figure 1 Chest radiograph (A) showing inhomogeneous opacities in the apex of the left lung (arrow). Ultrasound of the abdomen ( $B$ and $C$ ) reveals an ill-defined hypoechoic mass in the head of the pancreas (block arrow) in (B) and dilated common duct with choledocholithiasis. Contrast enhanced CT of the abdomen (D) axial image at the level of the pancreas reveals a round hypodense mass lesion with a focus of calcification (block arrow). 


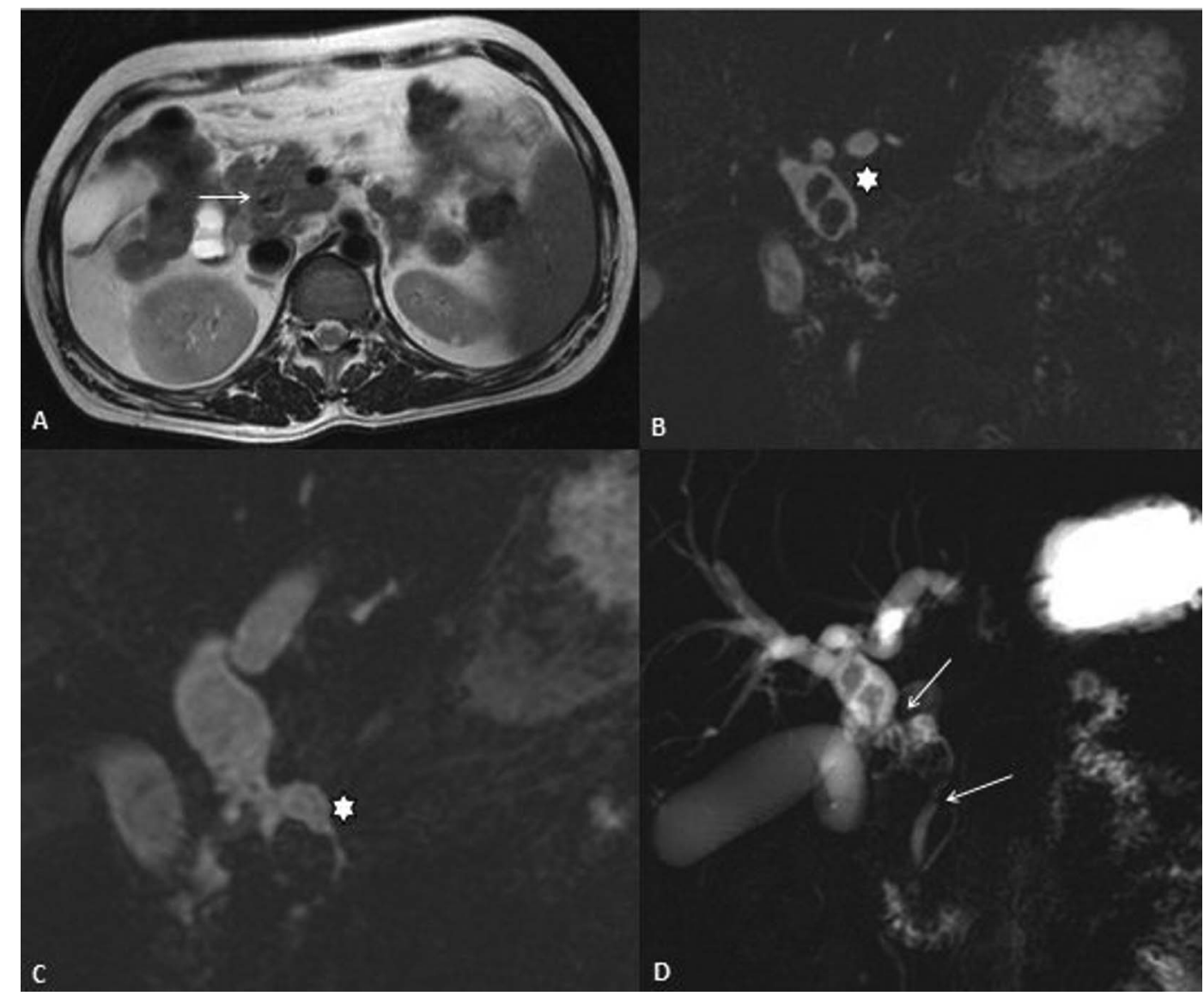

Figure 2 Magnetic resonance cholangiopancreatography (MRCP). T2-weighted axial image (A) reveals a hypointense round mass lesion in the head of the pancreas (arrow). Three-dimensional high resolution images (B and C) show regions of dilated common bile duct with choledocholithiasis (star). Single-shot MRCP image (D) reveals two regions of short segment strictures of common bile duct (arrows) with prestenotic dilation.

tuberculosis and tuberculous CBD strictures respond well to antituberculosis treatment.

\section{Learning points}

- Radiologists and clinicians must have a high index of suspicion whenever a pancreatic mass is found particularly in regions where tuberculosis is common.

- By diagnosing pancreatic tuberculosis with imaging modalities, unnecessary surgical procedures for the patient can be avoided.

- Pancreatic tuberculosis has an excellent response to antituberculosis treatment.
Acknowledgements The authors thank Dr Radha Gupta and Professor ML Prakash for their support and guidance.

Contributors SNR assisted in diagnosis and prepared the manuscript; SVC made the diagnosis and gave the final approval of manuscript.

Competing interests None.

Patient consent Obtained.

Provenance and peer review Not commissioned; externally peer reviewed.

\section{REFERENCES}

1 Raghavan P, Rajan D. Isolated pancreatic tuberculosis mimicking malignancy in an immunocompetent host. Case Rep Med 2012;2012:501246.

2 Kaushik N, Schoedel K, McGrath K. Isolated pancreatic tuberculosis diagnosed by endoscopic ultrasound-guided fine needle aspiration: a case report. J Pancreas 2006; 7:205-10.

3 Jethwani $\mathrm{U}$, Singh $\mathrm{G}$, Kandwal $\mathrm{V}$, et al. Tuberculosis of biliary tract: a rare cause of common bile duct stricture. OA Case Rep 2013;2:53.

Copyright 2014 BMJ Publishing Group. All rights reserved. For permission to reuse any of this content visit

http://group.bmj.com/group/rights-licensing/permissions.

BMJ Case Report Fellows may re-use this article for personal use and teaching without any further permission.

Become a Fellow of BMJ Case Reports today and you can:

- Submit as many cases as you like

- Enjoy fast sympathetic peer review and rapid publication of accepted articles

- Access all the published articles

- Re-use any of the published material for personal use and teaching without further permission

For information on Institutional Fellowships contact consortiasales@bmjgroup.com

Visit casereports.bmj.com for more articles like this and to become a Fellow 